\title{
ANALISIS TINGKAT PENGETAHUAN DAN SIKAP SISWI TERHADAP ANEMIA DAN DISTRIBUSI TABLET TAMBAH DARAH PROGRAM DI SMAN 11 PALEMBANG DAN SMAN 1 GELUMBANG MUARA ENIM SUMATERA SELATAN
}

Analysis Of Students 'Knowledge And Attitude Towards Anemia And Blood Added Tablet Distribution Programs In SMAN 11 Palembang and Sman 1 Gelumbang Muara Enim South Sumatra

\author{
Ahmad Sadiq ${ }^{1}$, Sartono ${ }^{2}$ \\ 1 Program Studi Diploma III Gizi, Politeknik Kesehatan Palembang \\ 2Program Studi Diploma IV Gizi, Politeknik Kesehatan Palembang \\ *) E-mail: sadiq@poltekkespalembang.ac.id dan 081319069870
}

\begin{abstract}
The prevalence of anaemia in women aged 15-24 years has the highest prevalence. This study aims to obtain a description of the characteristics, level of knowledge and attitudes of anaemia in female students and obtain information about the distribution of Blood Add Tablets (TTD) programs at SMU Negeri 11 Palembang and SMA Negeri 1 Gelumbang Muara Enim, South Sumatra Province in 2020. The research design includes descriptive research. analysis with a cross-sectional design. The population in this study were all class X, XI and XII students who were active students who were recorded from absences in both high schools totalling 1455 students. The sample was taken using a purposive sampling technique, namely all populations that met the criteria, namely students who were registered at SMAN 11 Palembang and SMA Negeri 1 Gelumbang schools and participated in filling out and sending back online research questionnaires. Analysis of the data used in univariate analysis and bivariate analysis. The number of samples in this study was 508 respondents consisting of 163 students of SMA Negeri 11 Palembang and 345 students of SMA Negeri 1 Gelumbang. Statistical test results obtained $p$-value $=$ 0.347 where $>0.05$, that there is no significant difference to the average level of knowledge of students at SMA Negeri 11 Palembang and SMA Negeri 1 Gelumbang. Based on the statistical test table, the average difference in attitudes results in the attitude scores of students of SMA Negeri 11 Palembang of 18.21 with a standard deviation of 20.058, while for students of SMA Negeri 1 Gelumbang the attitude value is 10.01 with a standard deviation of 2.050. The results of statistical values obtained $p$-value $=0.306$ where $p>0.05$ that there is no significant difference to the average attitude value of the students of SMA Negeri 1 Gelumbang and SMA Negeri 11 Palembang.
\end{abstract}

Keywords : Anemia, Blood Plus Tablets, Hemoglobin

\section{ABSTRAK}

Prevalensi anemia pada perempuan usia kelompok remaja 15-24 tahun memiliki prevalensi tertinggi. Penelitian bertujuan untuk mendapatkan deskripsi karakteristik, tingkat pengetahuan dan sikap anemia pada siswi dan memperolah informasi tentang pelaksaaan distribusi Tablet Tambah Darah (TTD) program di SMU Negeri 11 Palembang dan SMA Negeri 1 Gelumbang Muara Enim Provinsi Sumatera Selatan Tahun 2020. Disain penelitian termasuk penelitian deskriftif analitik dengan rancangan crossecsional. Populasi dalam penelitian ini seluruh siswi kelas kelas X, XI dan XII berstatus siswi aktif yang didata dari absen di kedua SMA yang seluruhnya berjumlah 1455 siswi. Sampel diambil dengan menggunakan tehnik purposive sampling yaitu semua populasi yang memenuhi kriteria yaitu siswi yang tercatat di sekolah SMAN 11 Palembang dan SMA Negeri 1 Gelumbang dan berpartisipasi dalam mengisi serta mengirim kembali kuesioner penelitian secara online. Analisis data yang digunakan adalah analisis univariat dan analisis bivariat. Jumlah sampel dalam penelitian ini sebanyak 508 responden yang terdiri dari siswi SMA Negeri 11 Palembang senamyal 163 siswi dan SMA Negeri 1 Gelumbang sebanyak 345 siswi. Hasil uji statistik didapatkan nilai $p=0,347$ di mana $>0,05$, bahwa tidak terdapat perbedaan yang signifikan terhadap ratarata tingkat pengetahuan siswi pada SMA Negeri 11 Palembang dan SMA Negeri 1 Gelumbang. Berdasarkan tabel uji statistik perbedaan rata-rata sikap mendapatkan hasil nilai sikap pada siswi SMA Negeri 11 Palembang sebesar 18,21 dengan standar deviasi 20,058, sedangkan untuk siswi SMA Negeri 1 Gelumbang nilai sikap sebesar 10,01 dengan standar deviasi 2,050. Hasil nilai statistik didapatkan nilai $p=0,306$ dimana $p>0,05$ bahwa tidak ada perbedaan yang signifikan terhadap rata-rata nilai sikap pada siswi SMA Negeri Negeri 1 Gelumbang dan SMA Negeri 11 Palembang.

Kata Kunci : Anemia, Tablet Tambah Darah, Hemoglobin

\section{PENDAHULUAN}

Di Indonesia anemia merupakan salah satu masalah kesehatan masyarakat yang dapat dialami oleh semua kelompok umur mulai dari balita sampai usia lanjut. Hasil Riset Kesehatan Dasar (Riskesdas) 2018 menunjukkan bahwa prevalensi anemia pada kelompok perempuan usia 15 - 24 tahun 
sebesar 84,6\% (Kemenkes RI, 2019).

Sebagian besar penyebab anemia di Indonesia adalah kekurangan zat besi yang diperlukan untuk pembentukan hemoglobin $(\mathrm{Hb})$. Kekurangan zat besi dalam tubuh tersebut disebabkan antara lain karena ; konsumsi zat besi yang kurang terutama yang berasal dari hewani, kebutuhan zat besi yang meningkat pada masa remaja dan kehilangan zat besi yang meningkat akibat menstruasi. (Kementrian Kesehatan RI, 2017). Beberapa penelitian menunjukkan prevalensi anemia masih tinggi pada remaja putri. Penelitian di SMP dan SMA di Kota Bengkulu dengan jumlah sampel sebesar 1200 siswi mendapatkan hasil prevalensi anemia pada remaja di Kota Bengkulu sebesar $43 \%$ dan salah satu faktor risiko kejadian anemia tersebut adalah pola makan remaja tidak baik yaitu sebesar 79,2\% Suryani Desi, dkk, 2015). Penelitian ini sejalan dengan hasil penelitian yang dilakukan pada remaja putri di Jurusan Gizi Poltekkes Kemenkes Semarang mendapatkan prevalensi anemia sebesar 59,1 \%, semua responden yang diamati memiliki asupan zat besi yang kurang baik rata-rata $34,4 \%$ dari AKG. (Agustina, et. al, 2017).

Penelitian Hesti PS, 2016 pada remaja putri di Banyumas mendapatkan hasil asupan zat besi pada remaja putri di perkotaan dan perdesaan menunjukkan bahwa sebagian besar sampel memiliki asupan zat besi yang kurang, yaitu sebanyak $95,7 \%$ remaja putri perkotaan dan 100\% remaja putri perdesaan. Hal ini tidak lepas dari pola makan remaja yang cenderung tinggi lemak dan karbohidrat sederhana

Hasil penelitan Sartono, (2019) yang melalukan pengukuran terhadap 188 siswi kelas XI MIA dan IPS SMA Negeri 6 Palembang mendapatkan hasil 37,2\% siswi menderita anemia. Faktor risiko terjadinya anemia tersebut diantaranya adalah $56,8 \%$ asupan zat besi yang tidak cukup dan sebanyak $94,3 \%$ asupan serat kurang. Sri Mulasih, 2017 melakukan penelitian terhadap 155 siswi SMK Nusa Bhakti Semarang. Hasil peneltian menunjukkan adanya hubungan yang signifikan antara pengetahuan remaja putri tentang anemia dengan perilaku pencegahan anemia pada saat menstruasi di SMK Nusa Bhakti Semarang. Sinta 2019 yang melakukan penelitian pada 109 siswi SMK Depok mendapatkan hasil pengetahuan merupakan salah satu faktor yang berhubungan dengan terjadinya anemia. Kegiatan promotif melalui Edukasi gizi adalah pendekatan edukatif untuk meningkatkan pengetahuan dan sikap remaja terhadap gizi. Semakin tinggi pengetahuan gizi akan berpengaruh terhadap sikap dan perilaku konsumsi makanan.(Fitrianti, 2016).

Defisiensi besi walaupun belum disertai anemia defisiensi besi dan anemia ringan sudah cukup menimbulkan gejala seperti lesu, lemah, letih, lelah dan lalai (5L). Hal ini diakibatkan oleh menurunnya kadar oksigen yang dibutuhkan oleh jaringan tubuh, termasuk otot untuk aktifitas fisik dan otak untuk berfikir. Anemia pada masa remaja berisiko untuk terjadinya defisiensi besi pada saat hamil.(Kementrian Kesehatan RI, 2017)

Kelompok usia remaja merupakan kelompok sasaran strategis karena masih berada pada proses belajar sehingga mudah menyerap pengetahuan. Penelitian mengenai peran pendidikan gizi yang dilakukan oleh Zulaekah (2009), menyatakan bahwa ada pengaruh yang positif mengenai pengetahuan gizi dan peningkatan kadar hemoglobin setelah adanya pendidikan gizi. Pengetahuan atau kognitif merupakan domain yang sangat penting untuk terbentuknya tindakan seseorang.(Notoatmodjo, 2003).

Remaja puteri mempunyai risiko yang lebih tinggi terkena anemia daripada remaja putera. Alasan pertama karena setiap bulan pada remaja puteri mengalami haid. Seorang wanita yang mengalami haid yang banyak selama lebih dari lima hari dikhawatirkan akan kehilangan besi, sehingga membutuhkan besi pengganti lebih banyak daripada wanita yang haidnya hanya tiga hari dan sedikit. Alasan kedua adalah karena remaja puteri seringkali menjaga penampilan, keinginan untuk tetap langsing atau kurus sehingga berdiet dan mengurangi makan. Diet yang tidak seimbang dengan kebutuhan zat gizi tubuh akan menyebabkan tubuh kekurangan zat gizi yang penting seperti besi.(Arisman, 2008).

Salah satu upaya yang telah dilakukan pemerintah untuk mendukung gerakan 1000 HPK, khususnya dalam menanggulangi masalah anemia pada remaja adalah melalui pemberian suplementasi Tablet Tambah Darah (TTD) berupa zat besi $(60 \mathrm{mg}$ $\mathrm{FeSO}$ ) dan asam folat $(0.25 \mathrm{mg})$. Pemerintah Indonesia sejak tahun 1997 telah merintis langkahlangkah baru dalam upaya mencegah dan menanggulangi anemia gizi pada Wanita Usia Subur (WUS) dengan mengintervensi lebih dini lagi yaitu sejak usianya masih remaja, dikarenakan intervensi yang dilakukan pada saat WUS anemia saat hamil tidak dapat mengatasi masalah anemia. Kelompok remaja putri merupakan sasaran strategis dari program perbaikan gizi untuk memutus siklus masalah agar tidak meluas ke generasi selanjutnya.(Bapenas Rl, 2012).

Masih tingginya prevalensi anemia pada remaja putri di Sumatera Selatan dan telah dilaksanannya program upaya pencegahan anemia melalui program pemerintah, hal inilah yang melatarbelakangi dilaksanakannya penelitian ini. Pemilihan 2 SMU yang terpilih yaitu SMU yang di wilayah perkotaan yaitu SMU 11 Palembang dan wilayah Kabupaten yaitu SMU Negeri 1 Gelumbang Muara Enim diharapkan dapat mewakili informasi 
tentang pengetahuan anemia dan pelaksanaan program distribusi tablet zat besi bagi remaja di sekolah di Sumatera Selatan. Masalah anemia gizi besi masih menjadi masalah gizi mikro di negara berkembang. Anemia gizi besi merupakan penyebab utama Disability Adjusted Life Years (DALY's) pada remaja putri dan menurunkan imunitas, produktivitas, prestasi belajar.

\section{METODE}

Penelitian ini akan dilakukan pada siswi di SMA Negeri 11 Palembang dan siswi SMA Negeri 1 Gelumbang Kabupaten Muara Enim. Ruang lingkup penelitian ini termasuk dalam bidang gizi masyarakat yaitu untuk menganalisis tingkat pengetahuan siswi terhadap anemia dan informasi pelaksanaan distribusi tablet tambah darah program pemerintah di sekolah. Pengambilan data dilakukan melalui kuesioner online yang akan dibagikan kesekolah melalui guru UKS pada bulan September 2020. Rancangan dalam penelitian ini adalah deskriptif dimana peneliti melaksanakan penelitian dengan metode survey yaitu penyebaran kuesioner secara online kepada sampel dalam hal ini siswi untuk mendeskripsikan tingkat pengetahuan, sikap, opini, perilaku, atau karakteritik responden terkait anemia.

Populasi dalam penelitian ini adalah seluruh siswi kelas kelas X, XI dan XII di SMA Negeri 11 Palembang dan SMA Negeri 1 Gelumbang masingmasing setiap sekolah berjumlah : 1469 siswi. Sampel diambil dengan menggunakan tehnik purposive sampling yaitu semua populasi yang memenuhi kriteria yaitu siswi yang tercatat di sekolah SMAN 11 Palembang dan SMA Negeri 1 Gelumbang dan mengisi kuesioner secara online.

Analisis univariat berguna untuk memberikan informasi tentang persentase jumlah pada masingmasing variabel, baik variabel dependen yaitu status gizi dan status anemia maupun variabel independen tingkat pengetahuan, sikap dan pelaksanaan distribusi tablet tambah darah disekolah. Hasil analisis disajikan dalam bentuk tabel distribusi frekuensi. Hasil analisis univariat pada masingmasing variabel disajikan secara berbeda antara Siswi SMA Negeri 11 Palembang dan SMA Negeri 1 Gelumbang. Untuk mendapatkan perbedaan variasi data kedua kelompok yang independen yaitu ratarata tingkat pengetahuan siswi terhadap anemia pada siswi SMA Negeri 11 Palembang dan SMA Negeri 1 Gelumbang dilakukan uji T.

\section{HASIL \\ Tingkat Pengetahuan}

Tingkat pengetahuan responden diperolah dari hasil skor penilaian kuesioner yang diisi oleh responden. Seluruh responden sebanyak 508 siswi (100) mengisi kuesioner tingkat pengetahuan yang hasilnya di kelompokkan berdasarkan 3 katagori yaitu tingkat pengetahuan baik, cukup dan sedang.

Tabel 1

Distribusi Frekuensi Tingkat Pengetahuan Responden Tentang Anemia Siswi di SMA Negeri 11 Palembang dan SMA Negeri 1 Gelumbang Tahun 2020

\begin{tabular}{ccc}
\hline $\begin{array}{c}\text { Tingkat } \\
\text { Pengetahuan }\end{array}$ & $\begin{array}{c}\text { Frekuensi } \\
(\mathrm{n})\end{array}$ & $\begin{array}{c}\text { Persentase } \\
(\%)\end{array}$ \\
\hline Baik & 145 & 28,5 \\
Cukup & 329 & 64,8 \\
Kurang & 34 & 6,7 \\
\hline Jumlah & $\mathbf{5 0 8}$ & $\mathbf{1 0 0}$ \\
\hline
\end{tabular}

Responden yang mengisi kuesioner tingkat pengetahuan berjumlah 508 siswi. Berdasarkan tabel diatas didapatkan sebagian besar responden memiliki tingkat pengetahuan katagori cukup yaitu sebanyak 320 siswi $(64,8 \%)$. Untuk katagoti tingkat pengetahuan baik sebanyak 145 siswi $(28,5 \%)$ dan terendah adalah tingkat pengetahuan kurang sebanyal 34 siswi $(6,75 \%)$. Untuk selengkapnya dapat dilihat pada tabel 4.6 dibawah ini

\section{Sikap Responden}

Hasil penelitian tentang sikap responden terhadap anemia dapat dilihat pada tabel di bawah ini.

Tabel 2

Distribusi Frekuensi Sikap Responden Tentang Anemia Siswi SMA Negeri 11 Palembang dan SMA Negeri 1 Gelumbang Tahun 2020

\begin{tabular}{ccc}
\hline Sikap & $\begin{array}{c}\text { Frekuensi } \\
\text { (n) }\end{array}$ & $\begin{array}{c}\text { Persentase } \\
(\%)\end{array}$ \\
\hline Positif & 293 & 57,7 \\
Negatif & 215 & 42,3 \\
\hline Jumlah & $\mathbf{5 0 8}$ & $\mathbf{1 0 0}$ \\
\hline
\end{tabular}

Seluruh responden sebanyak 508 (100\%) siswi mengisi kuesioner sikap mereka tentang anemia. Berdasarkan tabel diatas didapatkan sebesar 293 siswi $(57,7 \%)$ sebagian besar memiliki sikap dengan katagori positif. Jumlah ini lebih besar jika dibandingkan dengan responden yang memiliki katagori sikap negatif yaitu sebanyak 215 siswi atau $42,3 \%$

\section{Pemeriksaan Hemoglobin ( $\mathrm{Hb})$}

Pemeriksaan $\mathrm{Hb}$ yang dilakukan oleh responden secara mandiri untuk mengetahui kadar $\mathrm{Hb}$ dalam upaya mencegah terjadinya anemia dapat dilihat pada tabel berikut ini. Informasi tentang apakah pernah responden melakukan pemeriksaan $\mathrm{Hb}$ secara mandiri dapat dilihat pada tabel dibawah ini. 
Tabel 3

Distribusi Frekuensi Pemeriksaan Hb Mandiri Siswi SMA Negeri 11 Palembang dan SMA Negeri 1 Gelumbang Tahun2020

\begin{tabular}{cccc}
\hline & SMA Negeri & SMA & Jumlah \\
Pemeriksa & 11 & Negeri 1 & \\
an $\mathrm{Hb}$ & Palembang & Gelumban &
\end{tabular}

\begin{tabular}{ccccccc} 
& \multicolumn{7}{c}{$\mathrm{g}$} \\
\cline { 2 - 7 } & $\mathrm{n}$ & $\%$ & $\mathrm{n}$ & $\%$ & $\mathrm{n}$ & $\%$ \\
\hline Pernah & 9 & 5,5 & 32 & 10 & 41 & 8 \\
\hline Tidak & 154 & 94, & 313 & 90 & 467 & 92 \\
Pernah & & 5 & & & & \\
\hline Jumlah & 163 & 100 & 345 & 100 & 508 & 100 \\
\hline
\end{tabular}

Tabel di atas menunjukkan dari 508 responden hampir seluruh responden 467 siswi $(92 \%)$ menyatakan tidak pernah melakukan pemeriksaan $\mathrm{Hb}$ secara mandiri sebagai upaya skrining mengetahui kadar hemoglobin darah. Berdasarkan asal sekolah menunjukkan hasil yang sama baik di SMA Negeri 11 Palembang $(94,5)$ dan di SMA Negeri 1 Gelumbang (90\%) sebagian besar responden tidak pernah memeriksakan $\mathrm{Hb}$.

\section{Pemeriksaan Hemoglobin $(\mathrm{Hb})$ Program di Sekolah}

Informasi tentang adanya program pemeriksaan $\mathrm{Hb}$ di sekolah yang merupakan program pemerintah yang dilakukan oleh pihak sekolah yang merupakan upaya pencegahan anemia dapat dilihat pada tabel dibawah ini.

Tabel 4

Distribusi Frekuensi Kegiatan Pemeriksaan $\mathrm{Hb}$ Program di Sekolah SMA Negeri 11 Palembang dan SMA Negeri 1 Gelumbang Tahun 2020

\begin{tabular}{|c|c|c|c|c|c|c|}
\hline \multirow[t]{2}{*}{$\begin{array}{c}\text { Pemeriksaa } \\
n \mathrm{nb}\end{array}$} & \multicolumn{2}{|c|}{$\begin{array}{c}\text { SMA } \\
\text { Negeri } 11 \\
\text { Palemban } \\
\mathrm{g}\end{array}$} & \multicolumn{2}{|c|}{$\begin{array}{c}\text { SMA } \\
\text { Negeri } 1 \\
\text { Gelumban } \\
\mathrm{g}\end{array}$} & \multicolumn{2}{|c|}{ Jumlah } \\
\hline & $\mathrm{n}$ & $\%$ & $\mathrm{n}$ & $\%$ & $\mathrm{n}$ & $\%$ \\
\hline Pernah & 22 & $\begin{array}{c}13 \\
5\end{array}$ & 33 & 9,6 & 55 & $\begin{array}{c}10 \\
8\end{array}$ \\
\hline Tidak & 13 & 82 & 29 & 86 & 43 & 84, \\
\hline Pernah & 3 & & 8 & 4 & 1 & 9 \\
\hline Tidak & 8 & 4,9 & 14 & 4,0 & 22 & 4,3 \\
\hline Menjawab & & & & & & \\
\hline Jumlah & $\begin{array}{c}16 \\
3\end{array}$ & 100 & $\begin{array}{c}34 \\
5\end{array}$ & 100 & $\begin{array}{c}50 \\
8\end{array}$ & 100 \\
\hline
\end{tabular}

Dari 508 responden yang memberikan informasi tentang pemeriksaan $\mathrm{Hb}$ yang dilakukan oleh siswi, mendapatkan hasil sebagian besar 431 $(84,9 \%)$ responden dari kedua SMA menyatakan disekolahnya tidak pernah dilakukan pemeriksaan $\mathrm{Hb}$ kepada siswi. Dalam penelitian ini hanya 55 responden $(10,8 \%)$ menyatakan pernah diperiksa $\mathrm{Hb}$ nya. Terdapat 22 responden tidak $(4,3 \%)$ tidak memberikan jawaban

\section{Sosialisasi Tablet Tambah Darah Di Sekolah}

Penelitian ini juga mendapatkan informasi apakah pihak sekolah dalam hal ini UKS atau puskesmas pernah melakukan sosialisasi program pemerintah tentang anemia remaja putri dan tablet tambah darah di sekolah. Hasil yang di dapat dilihat pada tabel di bawah ini :

Tabel 5

Distribusi Frekuensi Pelaksanaan Sosialisasi Anemia

Remaja Putri SMA Negeri 11 Palembang dan SMA Negeri 1 Gelumbang

\begin{tabular}{ccccccc}
\multicolumn{7}{c}{ Negeri 1 Gelumbang } \\
\hline Sosialisasi & $\begin{array}{c}\text { SMA } \\
\text { Negeri 11 } \\
\text { Palembang }\end{array}$ & \multicolumn{2}{c}{$\begin{array}{c}\text { Segeri 1 } \\
\text { Gelumbang }\end{array}$} & Jumlah \\
& $\mathrm{n}$ & $\%$ & $\mathrm{n}$ & $\%$ & $\mathrm{n}$ & $\%$ \\
\hline $\begin{array}{c}\text { Pernah } \\
\text { Tidak }\end{array}$ & 119 & 73 & 272 & 78,8 & 391 & 77 \\
$\begin{array}{c}\text { Pernah } \\
\text { Tidak } \\
\text { Menjawab }\end{array}$ & 6 & 3,3 & 69 & 20 & 107 & 21 \\
\hline Jumlah & 163 & 100 & 345 & 100 & 508 & 100 \\
\hline
\end{tabular}

Tabel tersebut diatas menunjukkan dari 508 responden sebanyak 391 responden $(77 \%)$ menyatakan bahwa di sekolah mereka pernah dilakukan sosialisasi terkait anemia dan tablet tambah darah dan terdapat $21 \%$ responden menyatakan tidak pernah.

\section{Distribusi Tablet Tambah Darah di Sekolah}

Tabel 6

Distribusi Tablet Tambah Darah di SMA Negeri 1 Palembang dan SMA Negeri 1 Gelumbang Tahun 2020

\begin{tabular}{|c|c|c|c|c|c|c|}
\hline \multirow[t]{2}{*}{$\begin{array}{l}\text { Distribusi } \\
\text { Tablet Fe }\end{array}$} & \multicolumn{2}{|c|}{$\begin{array}{c}\text { SMA } \\
\text { Negeri } 11 \\
\text { Palembang }\end{array}$} & \multicolumn{2}{|c|}{$\begin{array}{c}\text { SMA Negeri } \\
1 \\
\text { Gelumbang }\end{array}$} & \multicolumn{2}{|c|}{ Jumlah } \\
\hline & $\mathrm{n}$ & $\%$ & $\mathrm{n}$ & $\%$ & $n$ & $\%$ \\
\hline Pernah & 134 & 82,2 & 272 & 78,8 & 406 & 80 \\
\hline $\begin{array}{l}\text { Tidak } \\
\text { Pernah }\end{array}$ & 22 & 13,5 & 69 & 20 & 91 & 18 \\
\hline $\begin{array}{c}\text { Tidak } \\
\text { Menjawab }\end{array}$ & 7 & 4,3 & 4 & 1,2 & 11 & 2 \\
\hline Jumlah & 163 & 100 & 345 & 100 & 508 & 100 \\
\hline
\end{tabular}

Sebagian besar responden 406 siswi $(80 \%)$ yang berasal dari kedua sekolah menyatakan bahwa disekolah mereka pernah mendapatkan Tablet Fe yang didistribusikan oleh pihak sekolah. Data Riskesdas (2018) menunjukkan sebanyak $76,2 \%$ remaja puteri mendapatkan tablet tambah darah (TTD). Dari jumlah tersebut sebanyak $80,9 \%$ diantaranya mendapatkan TTD di sekolah dan selebihnya sebesar 19,1\% 
menyatakan tidak didapatkan dari sekolah. Siswi yang tidak mendapatkan TTD sama sekali yaitu sebesar $23,8 \%$. Tingkat konsumsi TTD yang $<52$ butir sebesar $98,6 \%$ dan yang mengkonsumsi $\geq 52$ butir sebesar $1,4 \%$. Hasil penelitian ini sejalan dengan hasil Riskesdas (2018), yang menunjukkan remaja mendapat TTD cukup tinggi. Remaja puteri yang mendapatkan tablet tambah darah (TTD) sebesar $76,2 \%$ yang terdiri dari sebanyak $80,9 \%$ diantaranya mendapatkan TTD di sekolah dan 19,1\% menyatakan tidak didapatkan dari sekolah. Sedangkan yang tidak mendapatkan TTD sama sekali yaitu sebesar $23,8 \%$. Tingkat konsumsi TTD yang < 52 butir sebesar $98,6 \%$ dan yang mengkonsumsi $\geq 52$ butir sebesar $1,4 \%$.

\section{Konsumsi Tablet Tambah Darah di Sekolah}

Pengolahan data kuesioner terkait apakah sisiwi meminum tablet tambah darah yang diberikan di sekolah dapat dilihat pada tabel di bawah ini.

Tabel 7

Distribusi Responden MeminumTablet Tambah Darah di SMA Negeri 11 Palembang dan SMA Negeri 1 Gelumbang Tahun 2020

\begin{tabular}{|c|c|c|c|c|c|c|}
\hline \multirow[t]{2}{*}{$\begin{array}{l}\text { Minum } \\
\text { Tablet Fe }\end{array}$} & \multicolumn{2}{|c|}{$\begin{array}{c}\text { SMA } \\
\text { Negeri } 11 \\
\text { Palembang }\end{array}$} & \multicolumn{2}{|c|}{$\begin{array}{c}\text { SMA } \\
\text { Negeri } 1 \\
\text { Gelumbang }\end{array}$} & \multicolumn{2}{|c|}{ Jumlah } \\
\hline & $\mathrm{n}$ & $\%$ & $n$ & $\%$ & $\mathrm{n}$ & $\%$ \\
\hline Ya & 96 & 58,9 & 271 & 78,6 & 367 & 72,2 \\
\hline Tidak & 56 & 34,4 & 50 & 14,4 & 106 & 20 \\
\hline Tidak & 11 & 6,7 & 24 & 7 & 35 & 6,9 \\
\hline Menjawab & & & & & & \\
\hline Jumlah & 163 & 100 & 345 & 100 & 508 & 100 \\
\hline
\end{tabular}

Dari 408 responden $(80 \%)$ yang menyatakan mendapat tablet tambah di sekolah, $72,2 \%$ siswi menyatakan meminum Tablet Tambah Darah tersebut, Berdasarkan asal sekolah siswi SMA Negeri 1 Gelumbang yang mengkonsumsi tablet tambah darah sebesar $72,2 \%$ sedangkan SMA Negeri 11 Palembang sebesar $58,6 \%$.

\section{Alasan Tidak Meminum Tablet Tambah Darah}

Tabel.8

Distribusi Frekuensi Alasan Responden Tidak Meminum Tablet Tambah Darah SMA Negeri 11 Palembang dan SMA Negeri 1 Gelumbang Tahun

\begin{tabular}{|c|c|c|c|c|c|c|}
\hline \multirow{3}{*}{$\begin{array}{c}\text { Alasan Tidak } \\
\text { Minum } \\
\text { Tablet Fe }\end{array}$} & \multicolumn{4}{|c|}{2020} & \multicolumn{2}{|c|}{ Jumlah } \\
\hline & $\begin{array}{r}\mathrm{Ne} \\
\text { Pale }\end{array}$ & $\begin{array}{l}\text { MA } \\
\text { eri } 11 \\
\text { abang }\end{array}$ & & $\begin{array}{l}\text { MA } \\
\text { eri } 1 \\
\text { nbang }\end{array}$ & & \\
\hline & $\mathrm{n}$ & $\%$ & $\mathrm{n}$ & $\%$ & $\mathrm{n}$ & $\%$ \\
\hline - Lupa & 13 & 20 & 61 & 71,8 & 74 & 49,3 \\
\hline $\begin{array}{l}\text { Tidak Suka } \\
\text { Dengan Bau, }\end{array}$ & 18 & 27,7 & 17 & 20 & 35 & 23,3 \\
\hline
\end{tabular}

\begin{tabular}{lcccccc}
\hline $\begin{array}{l}\text { bentuk, rasa } \\
\text { dan takut }\end{array}$ & & & & & & \\
$\begin{array}{l}\text { meminumnya } \\
- \text { Tidak }\end{array}$ & 3 & 4,61 & 0 & 0 & 3 & 2 \\
$\begin{array}{l}\text { diizinkan } \\
\text { orang tua }\end{array}$ & & & & & & \\
- Merasa & 16 & 24,6 & 7 & 8,2 & 23 & 15,3 \\
$\begin{array}{l}\text { tidak anemia } \\
\text { - Alasan lain }\end{array}$ & 15 & 23 & 0 & 0 & 15 & 10 \\
\hline Jumlah & 65 & 100 & 85 & 100 & 150 & 100 \\
\hline
\end{tabular}

Tabel tersebut di atas menunjukkan alasan responden yang tidak minum tablet $\mathrm{Fe}$ yang dibagikan oleh pihak sekolah. Dari 150 responden yang menyatakan alasan tidak minum tablet $\mathrm{Fe}$, persentase tertinggi berturut-turut adalah $74 \%$ responden menyatakan lupa, $35 \%$ responden menyatakan tidak suka bau, bentuk, rasa dan takut meminumya dan $23 \%$ responden dengn alasan tidak anemia. Dalam penelitian ini terdapat tidak responden tidak minum tablet Fe karena tidak diizinkan orang tua.

Hari Minum Tablet Fe di Sekolah

Berdasarkan kuseioner yang diajukan kepada responden didapatkan informasi tentang ada tidaknya kegiatan di sekolah dalam melakukan sosialisasi tentang anemia melalui hari minum tablet tambah darah didapat disajikan dalam tabel berikut ini.:

Tabel 9

Sosialisasi Hari Minum Tablet Fe Bersama di SMA Negeri 11 Palembang dan SMA Negeri 1 Gelumbang Tahun 2020

\begin{tabular}{|c|c|c|c|c|c|c|}
\hline \multirow{2}{*}{$\begin{array}{c}\text { Hari Minum } \\
\text { Tablet } \\
\text { Fe } \\
\text { Bersama }\end{array}$} & \multicolumn{2}{|c|}{$\begin{array}{c}\text { SMA } \\
\text { Negeri } 11 \\
\text { Palembang } \\
\end{array}$} & \multicolumn{2}{|c|}{$\begin{array}{c}\text { SMA Negeri } \\
1 \\
\text { Gelumbang } \\
\end{array}$} & \multicolumn{2}{|c|}{ Jumlah } \\
\hline & $\mathrm{n}$ & $\%$ & $n$ & $\%$ & $n$ & $\%$ \\
\hline Pernah & 27 & 16,6 & 14,2 & 49 & 76 & 15 \\
\hline $\begin{array}{l}\text { Tidak } \\
\text { Pernah }\end{array}$ & 129 & 79,1 & 81,7 & 282 & 411 & 81 \\
\hline $\begin{array}{l}\text { Tidak } \\
\text { Menjawab }\end{array}$ & 7 & 4,3 & 4,1 & 14 & 21 & 4,4 \\
\hline Jumlah & 163 & 100 & 345 & 100 & 508 & 100 \\
\hline
\end{tabular}

Dari 508 responden yang mengisi kuesioner penelitian, sebanyak 411 responden (81\%) menyatakan bahwa di kedua sekolah tidak pernah melakukan upaya pencegahan anemia melalui program hari minum tablet tambah darah secara bersama di sekolah. 
Tabel 10

Tenaga Yang Memberikan Penyuluhan Tablet Tambah Darah SMA Negeri 11 Palembang dan SMA Negeri 1 Gelumbang Tahun 2020

\begin{tabular}{ccccccc}
\hline & \multicolumn{2}{c}{$\begin{array}{c}\text { SMA } \\
\text { Tenaga }\end{array}$} & \multicolumn{2}{c}{$\begin{array}{c}\text { Negeri 11 } \\
\text { Seger } 1\end{array}$} & \multicolumn{2}{c}{ Jumlah } \\
Distribusi & Palembang & \multicolumn{2}{c}{ Gelumbang } & & \\
\cline { 2 - 7 } TTD & $\mathrm{n}$ & $\%$ & $\mathrm{n}$ & $\%$ & $\mathrm{n}$ & $\%$ \\
\hline Guru Uks & 63 & 38,7 & 246 & 71,3 & 309 & 60,8 \\
$\begin{array}{c}\text { Tenaga } \\
\text { Puskesmas }\end{array}$ & 23 & 14,1 & 29 & 8,4 & 52 & 10,2 \\
$\begin{array}{c}\text { Perwakilan } \\
\text { Siswa }\end{array}$ & 63 & 38,7 & 27 & 7,8 & 90 & 17,7 \\
$\begin{array}{c}\text { Tidak } \\
\text { Menjawab }\end{array}$ & 14 & 8,6 & 43 & 12,5 & 57 & 11,2 \\
\hline Jumlah & 163 & 100 & 345 & 100 & 508 & 100 \\
\hline
\end{tabular}

Perbedaan Rata-Rata Tingkat Pengetahuan Pada Siswi SMA Negeri 11 Palembang dan Siswi SMA Negeri 1 Gelumbang Tahun 2020

Tabel 11

Distribusi Rata-Rata Tingkat Pengetahuan Responden Menurut Asal SMA Negeri 11 Palembang dan SMA Negeri 1 Gelumbang Tahun 2020

\begin{tabular}{lccccc}
\hline \multicolumn{1}{c}{$\begin{array}{c}\text { Asal } \\
\text { Sekolah }\end{array}$} & $\begin{array}{c}\text { Rata- } \\
\text { Rata }\end{array}$ & SD & SE & $\begin{array}{c}p \\
\text { value }\end{array}$ & N \\
\hline SMA & 71,87 & 8,908 & 0,698 & 0,347 & 163 \\
Negeri 11 & & & & & \\
$\begin{array}{l}\text { Palembang } \\
\text { SMA }\end{array}$ & 72,68 & 9,068 & 0,488 & & 345 \\
$\begin{array}{l}\text { Negeri 1 } \\
\text { Gelumbang }\end{array}$ & & & & & \\
\hline
\end{tabular}

Berdasarkan tabel uji statistik rata - rata tingkat pengetahuan Siswi SMA Negeri 11 Palembang adalah 71,87 dengan standar deviasi 8,908, sedangkan untuk Siswi SMA Negeri 1 Gelumbang rata-rata tingkat pengetahuan adalah 72,68 dengan standar deviasi 9,068. Hasil uji statistik didapatkan nilai $p=0,347$ dimana $>0,05$, maka dapat disimpulkan bahwa tidak terdapat perbedaan yang signifikan terhadap rata-rata tingkat pengetahuan siswi pada SMA Negeri 11 Palembang dan SMA Negeri 1 Gelumbang.

\section{Perbedaan Rata -Rata Sikap Pada Siswi SMA Negeri 11 Palembang dan SMA Negeri 1 Gelumbang}

Tabel 12

Distribusi Rata-Rata Sikap Responden Menurut Asal Sekolah SMA Negeri 11 Palembang dan SMA Negeri 1 Gelumbang Tahun 2020

\begin{tabular}{cccccc}
\hline Asal Sekolah & $\begin{array}{c}\text { Rata- } \\
\text { Rata }\end{array}$ & SD & SE & $\begin{array}{c}\boldsymbol{p} \\
\text { value }\end{array}$ & $\mathbf{N}$ \\
\hline SMA Negeri & 18,21 & 2,058 & 0,698 & 0,306 & 163
\end{tabular}

11

Palembang

SMA Negeri

$1 \quad 18,01 \quad 2,050 \quad 0,488 \quad 345$

Gelumbang

Berdasarkan tabel uji statistik perbedaan rata-rata sikap mendapatkan hasil nilai sikap pada siswi SMA Negeri 11 Palembang sebesar 18,21 dengan standar deviasi 20,058, sedangkan untuk siswi SMA Negeri 1 Gelumbang nilai sikap sebesar 10,01 dengan standar deviasi 2,050. Hasil nilai statistik didapatkan nilai $p=0,306$ dimana $p>0,05$ maka dapat disimpulkan bahwa tidak ada perbedaan yang signifikan terhadap rata-rata nilai sikap pada siswi SMA Negeri Negeri 1 Gelumbang dan SMA Negeri 11 Palembang.

\section{PEMBAHASAN}

Perbedaan Rata-Rata Tingkat Pengetahuan Pada Siswi SMA Negeri 11 Palembang dan Siswi SMA Negeri 1 Gelumbang Tahun 2020

Hasil ini relevan dengan hasil beberapa penelitian, diantaranya penelitian (Franssiske, Simanungkalit, \& Simarmata, (2019),terkait pengetahuan dan kejadian anemia pada siswi Kelas XI di SMA Muhammadiyah 4 Depok dan SMK Al-Hidayah mendapatkan hasil proporsi anemia sebesar $63,4 \%$. Didapatkan ada hubungan pengetahuan anemia dengan kejadian anemia remaja putri di SMA Muhammadiyah 4 Depok dan SMK Al-Hidayah Cinere. Dalam penelitian tersebut, pengetahuan anemia merupakan faktor yang paling dominan terjadinya anemia.

Penyuluhan tentang anemia merupakan salah satu cara yang dapat dilakukan untuk meningkatkan pengetahuan siswi tentang anemia. Hal ini berdasarkan rekomendasi WHO pada World Health Assembly (WHA) ke-65 yang menyepakati rencana aksi dan target global untuk gizi ibu, bayi, dan anak, dengan komitmen mengurangi separuh (50\%) prevalensi anemia Program Pencegahan \& Penanggulangan Anemia pada Rematri dan WUS 4 pada WUS pada tahun 2025. Menindaklanjuti rekomendasi tersebut maka pemerintah Indonesia melakukan intensifikasi pencegahan dan penanggulangan anemia pada rematri dan WUS dengan memprioritaskan pemberian TTD melalui institusi sekolah.

Penelitian Guswir, (2018), dilakukan pada 105 remaja putri di SMK Negeri 3 Padang Sampel terdiri dari 105 remaja putri, menggunakan teknik proposional random sampling. Metode penelitan dengan memberikan penyuluhan tentang anemia dengan menggunakan media leaflet dan video hasilnya 
berpengaruh dalam meningkatkan perubahan pengetahuan anemia pada remaja putri SMK Negeri 3 Padang

Hasil yang sama didapat dari penelitian Yunita, dkk yang menunjukkan status anemia pada siswi SMP 18 Surakarta sebesar 26,7\% dan dari penelitian tersebut disimpulkan terdapat hubungan antara pengetahuan konsumsi zat besi dengan kejadian anemia. Sesuai rekomendasi WHO tahun 2011, upaya penanggulangan anemia pada rematri dan WUS difokuskan pada kegiatan promosi dan pencegahan, yaitu peningkatan konsumsi makanan kaya zat besi, suplementasi TTD, serta peningkatan fortifikasi bahan pangan dengan zat besi dan asam folat. Upaya promosi dapat berupa peningkatan pengetahuan dan sikap siswi melalui kegiatan penyuluhan dan sosialisasi anemia dan gizi seimbang di sekolah yang dapat dilakukan lintas sekoral (Kementrian Kesehatan RI, 2016).

Pada penelitian dkk (2017) menyatakan bahwa tingkat pengetahuan gizi yang kurang mempunyai peluang sebesar 3,951 kali mengalami kejadian anemia dibandingkan dengan remaja puteri yang mempunyai tingkat pengetahuan gizi yang baik. Upaya promotif melalui edukasi gizi terkait anemia pada siswi juga dilakukan penelitian oleh Sari dkk (2018), pada 70 responden di SMA Negeri 2 and SMA Negeri 4 Banyumas. Hasil analisis statistik menunjukan terdapat perbedaan rerata kadar hemoglobin pada kelompok perlakuan antara sebelum dan sesudah edukasi gizi dari $12.17 \mathrm{~g} / \mathrm{dL}$ meningkat menjadi $12.68 \quad \mathrm{~g} / \mathrm{dL}(p=\quad 0,001)$. Skor pengetahuan subjek meningkat dari 16.03 2.30 menjadi 20.09 $\pm 2.21(p=0,000)$.

\section{Perbedaan Rata -Rata Sikap Pada Siswi SMA Negeri 11 Palembang dan SMA Negeri 1 Gelumbang}

Berdasarkan tabel uji statistik perbedaan rata-rata sikap mendapatkan hasil nilai sikap pada siswi SMA Negeri 11 Palembang sebesar 18,21 dengan standar deviasi 20,058, sedangkan untuk siswi SMA Negeri 1 Gelumbang nilai sikap sebesar 10,01 dengan standar deviasi 2,050. Hasil nilai statistik didapatkan nilai $p=0,306$ dimana $p>0,05$ maka dapat disimpulkan bahwa tidak ada perbedaan yang signifikan terhadap rata-rata nilai sikap pada siswi SMA Negeri Negeri 1 Gelumbang dan SMA Negeri 11 Palembang.

Penelitian yang berkaitan dengan tablet tambah darah yang dikonsumsi oleh responden dalam hal ini remaja putri berpengaruh terhadap efektifitas peningkatan kadar $\mathrm{Hb}$. Penelitian Penelitian yang dilakukan (Permatasari, 2018) di Kabupaten Tasikmalaya dengan program pemberian TTD secara mingguan dan 10 tablet selama menstruasi mengalami peningkatan kadar $\mathrm{Hb}$ sebanyak 0.48 \pm 1.04 g/dl.8 Program serupa yang dilakukan pada wanita usia subur di Vietnam mengalami peningkatan kadar $\mathrm{Hb}$ selama 3 bulan intervensi yakni rata-rata meningkat sebesar $9.6 \mathrm{~g} / \mathrm{dl} .7$ Berbeda halnya dengan program suplementasi besi yang dilakukan di Kota Bekasi pada siswi SMP dan SMA, tidak terjadi peningkatan kadar $\mathrm{Hb}$ setelah diberikan suplementasi.

Menurut Amir (2019) berdasarkan hasil review dari beberapa penelitian dapat disimpulkan bahwa faktor-faktor yang berhubungan dengan konsumsi TTD pada remaja putri di Indonesia yaitu dukungan guru $(O R=4,7)$, sikap $(O R=2,192)$, budaya $(\mathrm{OR}=2,517)$, juga dukungan keluarga. Faktor yang tidak kalah penting adalah perceived threat (ancaman yang dirasakan). Hasil review tersebut menunjukkan bahwa guru berperan 4,7 kali dalam keberhasilan program tablet tambah darah pada remaja putri

\section{KESIMPULAN}

Sebanyak 78,9\& siswi memberikan informasi bahwa mereka tidak pernah mendapatkan kartu tablet tambah darah yang diberikan oleh pihak sekolah/Puskesmas. Hasil uji statistik didapatkan nilai $p=0,347$ di mana >0,05, bahwa tidak terdapat perbedaan yang signifikan terhadap rata-rata tingkat pengetahuan siswi pada SMA Negeri 11 Palembang dan SMA Negeri 1 Gelumbang. Berdasarkan tabel uji statistik perbedaan rata-rata sikap mendapatkan hasil nilai sikap pada siswi SMA Negeri 11 Palembang sebesar 18,21 dengan standar deviasi 20,058, sedangkan untuk siswi SMA Negeri 1 Gelumbang nilai sikap sebesar 10,01 dengan standar deviasi 2,050. Hasil nilai statistik didapatkan nilai $p=0,306$ dimana $p>0,05$ bahwa tidak ada perbedaan yang signifikan terhadap rata-rata nilai sikap pada siswi SMA Negeri Negeri 1 Gelumbang dan SMA Negeri 11 Palembang.

\section{SARAN}

Rekomendasi yang dikemukan berikut ini merupakan masukan dari hasil analisis data yang didapatkan dalam penelitian ini. Bagi Institusi Sekolah meningkatkan koordinasi dengan sektoral dalam hal ini puskesmas selaku pembina kesehatan untuk meningkatkan edukasi kepada siswi terutama dalam upaya pencegahan anemia melalui pemeriksaan $\mathrm{Hb}$ secara mandiri jika program belum mencapai seluruh siswi. Memperbanyak media edukasi tentang anemia remaja putri disekolah berupa spanduk, banner ataupun leaflet di lingkungan sekolah. Meningkatkan upaya promotive dalam pencegahan anemia dengan cara mengadakan hari minum tablet tambah darah disekolah. Meningkatkan pengetahuan dan peran guru UKS dalam upaya pencegahan dan penanggulangan anemi di sekolah dengan mengikuti pelatihan melalui puskesmas. Bagi Responden siswi usia remaja putri kelompok berisiko tinggi untuk terjadinya anemia. 
Sebagai upaya pencegahan dapat mengkonsumsi gizi seimbang dan mengkonsumsi tablet tambah darah baik dari program pemerintah maupun mandiri. Melakukan skrining pemeriksaan $\mathrm{Hb}$ secara berkala untuk mengetahui status anemia

\section{UCAPAN TERIMA KASIH}

Terima kasih banyak peneliti kepada sekolah SMAN 11 Palembang dan SMAN 1 Gelumbang Kab. Muara Enim yang telah membantu dalam pemberian data selama penelitian ini. Terima kasih kepada Politeknik Kesehatan Palembang.

\section{DAFTAR PUSTAKA}

Agustina, Laksono, \& Indriyani. (2017). Determinan Risiko Kejadian Anemia Pada Remaja Putri Berdasarkan Jenjang Pendidikan di Kabupaten Kebumen. Universitas Negeri Semarang.

Amir, N., \& Djokosujono, K. (2019). Faktor - Faktor Yang Berhubungan dengan Konsumsi Tablet Tambah Darah (TTD) pada Remaja Putri di Indonesia. Kedokteran Dan Kesehatan, 119-129.

Arisman, M. . (2008). Gizi Dalam Daur Kehidupan. Jakarta: Kedokteran EGC.

Bapenas RI. (2012). Kerangka Kebijakan; Gerakan Sadar Gizi Dalam Rangka Seribu Hari Pertama Kehidupan (1000 HPK). Jakarta: Badan Perencanaan dan Pembangunan Nasional.

Fitrianti. (2016). Pengaruh Edukasi Gizi Dengan Ceramah dan Boklet Terhadap Peningkatan Pengetahuan dan Sikap Gizi Remaja Overweight,. Journal of Nutritional Collage, 5(4), 374-390.

Franssiske, S., Simanungkalit, \& Simarmata, O. S. (2019). Pengetahuan dan Perilaku Konsumsi Remaja Putri Yang Berhubungan Dengan Status Anemia. Buletin Penelitian Kesehatan, 47(3), 175 - 182.

Guswir. (2018). Pengaruh Penyuluhan Menggunakan Leaflet dan Video Terhadap Perubahan Pengetahuan Anemia Pada Remaja Putri Untuk Penceghan Anemia SMKN 3 Kota Padang Tahun 2018. Universitas Andalas.

Kemenkes RI. (2019). Hasil Riset Kesehatan Dasar Tahun 2018. In Kementrian Kesehatan RI (Vol. 53).

Kementrian Kesehatan RI. (2016). Pedoman dan Pencegahan dan Penanggulangan Anemia Pada Remaja Putri dan Wanita usia Subur. Jakarta: Direktorat Jenderal Gizi Masyarakat Kementrian Kesehatan RI.

Kementrian Kesehatan RI. (2017). Pedoman Penatalaksanaan Pemberian Tablet Tambah Darah, Dirjen Bina Gizi dan Kesehatan Ibu dan Anak. Jakarta: Kementerian Kesehatan RI.

Notoatmodjo, S. (2003). Pendidikan dan Perilaku Kesehatan. Jakarta: Rineka Cipta.

Permatasari, T. (2018). Efektifitas Program Suplementasi Zat Besi Pada Remaja Putri di Kota Bogor. Jurnal MKMI, 14(1).

Putri, R., Simanjuntak, B., \& Kusdalinah, K. (2017). Pengetahuan Gizi, Pola Makan dan Kepatuhan Konsumsi Tablet Tambah Darah Dengan Kejadian Anemia Remaja Putri. Jurnal Kesehatan, 8(3), 404-409.

Sartono, S. (2019). Determinasi Anemia Pada Siswi SMA Negeri 6 Palembang. Poltekkes Palembang. 